\title{
Times of the self in Kingston, Jamaica
}

And time is a dictator, as we know it. Where does it go? What does it do? Most of all, is it alive? Is it a thing that we cannot touch and is alive?

Nina Simone, 'Who Knows Where the Time Goes'

Jeanette, whose temporal knowledge and experience of time is the focus of this article, has belonged for many years to a predominantly female led Jamaican spiritist church called Revival zion or Revival 60. Ritual activity in Revival is charismatic and centres on trance, dance and healing in balm yards (Wedenoja 1989, Seaga 1969). For the adherent, all-important is a personal relationship with angels who guide, defend and act on their behalf. The Holy spirit and angels activate gifts inherent in the Revivalist. These gifts are idiosyncratic and they may have a 'good' or 'bad' moral character or both. Likewise, angels and other spiritual entities may send both 'good' and or 'evil' work for the adherent to undertake; though the expressed aim of Revival is to help not to harm others. Work on behalf of the angels is made meaningful by a further distinction between spiritual and temporal action (Wedenoja 1990:286). The temporal describes the time of everyday life, particularly everyday striving and suffering: the spiritual is transcendent but also continuously present, though for the most part hidden from the self. The Revivalist deploys personal spiritual gifts in response to temporal predicaments. It is this division or disjuncture as an aspect of Jamaican urban time that I investigate further here.

It is helpful to acknowledge at the outset Gell's criticism of 'pseudo-metaphysics' in anthropological discussions of time (Gell 1996). Pragmatically speaking, urban Jamaicans recognizably distinguish and plan regarding 'before', 'now' and 'after'. Similarly, they strategize in familiar ways taking 'where vis-à-vis when' and 'how long' into account. These instrumental qualities or capacities are not in doubt; and as Gell argues, it is unlikely they can fundamentally be doubted in any human social setting. There are some interesting aspects of the use of clock time to discuss in this regard (Birth 1999), and there are some significant debates concerning how time plays out syntactically and semantically in Creole languages of the kind that Jeanette speaks (Bickerton 1984, 
Patrick 1999, Riesman 1971); but, for brevity, I will leave these aspects aside.

Nonetheless, at least from a Kantian viewpoint, the possibility of experiencing time as change depends on the application of time categories that do not themselves change and which do not derive directly from the field of experience itself: 'time itself does not change but only something which is in time' (Kant 1949:33 my italics). In Revival zionism this transcendent time corresponds to the time of the angels and the holy spirit (alongside other, often malign, entities). Medieval theology used the term aevum to describe this 'time of the angels': angelic beings were considered to act in time but were not themselves of time. This parallels the view of Revivalists who nonetheless add Manichean complexities to it. So, we are concerned here with a metaphysics of time (we could say an ethnometaphysics, but it comes to the same). It is important to underline that the Revivalist understandings explored here are not shared by all Kingstonians.

Since the early Twentieth Century, Pentecostalism has been the largest religious movement in Jamaica, but there exist many other followings, including those associated with the longstanding elite, Catholic and Anglican, and those that have emerged from the margins, like Rastafari. In broad terms these all share eschatological features - a common 'Christian time' in which immediate human actions are symptomatic of how the world is unfolding toward salvation (Coleman 2011, Guyer 2007, Robbins 2001). Nonetheless, each offers a somewhat distinct mapping of time for the self who acts morally in it. So to adhere to a church is also to index diacritically not only one's position within what Austin-Broos has called a 'politics of moral order' but also vis-à-vis a politics of time (1997). Heuristically, in order to explore this further, the current article isolates facets of a Revivalist worldview, but these aspects are not presented by Revivalists themselves as a doctrine (cf. Wardle 2008).

Temporal experience, the time of everyday personal struggle, finds itself squeezed on two sides in Kingston. On the one hand, life for the Revivalist and for many other city dwellers is made rough by the pressure of lack of resources, especially money, which threatens to push existence backwards toward slavery days. On the other, the nearness of the Day of Judgement is frequently voiced in street speech. The individual struggles to decide what road to take in view 
of the Last Days. Often there seems only a thin membrane or even simultaneity between the presence of spiritual actors and everyday temporal activity. As Jeanette describes, the individual can simply be overtaken by the spirit which possesses their temporal body. Equally, urbanites sometimes talk of Kingston as hell in a literal sense. Indexings of irrealis possibility, hope and expectation have a strong charge in this setting, then, because they are poised against the imminent end of time; that is, the end of experience in time. It is in relation to the near future that Jeanette is taken over by the spirits and by her gifts and forced to prophesy and warn.

Nonetheless, access to the spiritual is highly individualized: there is little emphasis on standardizing or routinising religious norms, practices or images (though many images reiterate as we shall see later). Spiritually, Jeanette acts in the face of some who consider her religiously gifted, alongside others who see her as a 'madwoman'. Since the intentions of the angels are not unequivocally for the good, spiritual or eschatological striving cannot be directed unambiguously toward the good (and many people in Kingston view Revivalism as preeminently taken up with evil work). For Revivalists, the moral ambivalence of individual striving holds not only for living human beings: to varying degrees the dead, animals and plants may also work individually for good, bad and ambivalent ends. It is possible to make a virtue of evil work as I explain. Here, then, I explore the integration of Revival personhood (in particular its egalitarian metaphysics of time) vis-a-vis other facets of the urban setting. These include not only the kinds of claim poor urbanites are able to make on resources including money, property and work, but also their capacity to decrypt and predict the intentions of others around them.

\section{Elements of an urban temporality}

The poorest urban Jamaicans have every motivation to keep their economic expectations, strategic plans and other temporal constructs as open as possible (Wardle 2008). As I will indicate, recognition of the flexibility but also fragility of relationships in time is a correlate of a strongly developed political individualism and religious immanentism. Person-centred networks come to resemble the structure of nylon as individuals try to maintain chains of personal connection to distant others. Urbanites are associated with the street corner where they aggregate with close companions, but 'their 
corner' shifts and stretches with transfigured mutual aims. Likewise the compound yard, the emblematic site of family life, expands and transforms with phases of rural-urban-transnational arrival and departure and with regard to flows of money or barrels of comestibles remitted by migrant friends and kin in foreign.

Uneven bursts of inflation from the early 1990s, intensified during the economic crisis of 2007 onwards, continually disrupt the predictability of all kinds of exchanges: everyday street transactions and relationships must be re-valued and this endemic unpredictability becomes an expectation in its own right. Political terrorism, continuous and escalating since the 1960s, intermittently condenses urbanites in garrison communities or forces them to break from friends and family and flee to rural outliers until trouble simmers down (Eyre 1986, Wardle 2005). Hierarchical linkages between state authority, local leadership, urban neighbourhoods and corners often fracture into inter-community violence, as happened in 2010, when the United States judiciary sought to extradite the don of Tivoli Gardens, Christopher coke.

In this setting, Money, the most objective (generalisable) gauge of social standing, is both unstable in value and hard to come by: once gained, it is quickly redistributed within the sites of friendship and family: social interaction becomes, literally in many instances, a bet concerning money supply (Wardle 2005:88). Likewise, because the majority of urban dwellers have few legally enforceable property rights regarding city space, they can riot, overturn buses, burn mounds of tyres, but they have few points of institutional leverage over the web of enabling relationships of which they themselves are part (Kral 2006). Instead, they must reshape these networks: bore into the water main; capture electricity off the cables; turn old Honda vans into robot buses; reconnect to others using mobile phones instead of landlines (Maurer 2001, Horst and Miller 2006); create exchanges not through banknotes but around bags of mangoes and stored up bottles of white rum; gain access to the internet in order to vault barriers to communication.

In a marketing system characterised by paucity of owned resources, as Mintz observes, labour time must needs replace capital; and 'plenitude of time... reduces the urgency of standardization' in the formation of relationships and measurement of goods (1961:36). I will return later to how this applies not only to economic goods but to 
moral ones also - including the capacity to act in time. As I will show, the very particular 'gifts' of Revival zionists parallel the highly personalised and unstandardized quality of social relationships in this setting. There are a large number of characteristic phrases that Jamaicans use to describe the experience of acting vis-a-vis their economic circumstances - scuffle, jump around, try a thing, struggle; and there are an equally large number that reflect the sense of being underneath the weight of the social milieu - pressure, downpression, sufferer, sufferation. 'Me just sit down in a sufferation' typifies how the '-ation' suffix is often applied to describe being caught intransitively inside an oppressive social milieu. We have, then, ways of describing the small tactical masterings of flow that turn conjunctures into opportunities (timing); but also tropes indexing personal duration in the present (subjective enduring).

Jeanette's biography incorporates many of these characteristic elements. Having spent some of her early years in the countryside, Jeanette came through adoption to belong to a transnationally dispersed family focused on Aunt Erica; a Jamaican matriarch who spent half the year in New York and half the year in a semi-rural periphery of Kingston (Wardle 2000:43-60, 2008, 2010). Aunt Erica died in 1990 and from her Jeanette inherited the use of two small houses in the cognatically owned urban family yard that Erica built up. Unable to afford the probate fees, she does not have legal title over these dwellings. Alongside renting the second property, Jeanette has taken on a range of work - street side selling, running a bar, working as a household cleaner, and as a shop assistant (Wardle 2010). Currently she buys newspapers in bulk and sells these around the district. Now in her fifties, Jeanette is the head of her household and has an adult daughter and son, and another younger daughter.

\section{Gifts and angels: the self in time and 'in the spirit'}

Jeanette has been a Revivalist since the early 1990s. Once a historically important religious movement zion Revival is now one cult among very many in the capital. Like other members of this church, Jeanette gives special significance to spiritual gifts she has received from the Revival angels that the church celebrates. These gifts exist within herself as capacities for undertaking certain tasks. Sometimes they seem to have a subjectivity and compulsive agency of their own, while at other moments they are the 
means by which she brings about certain intentional effects. Jeanette suggests that the gifts were always present but were activated by her 'becoming a Christian', that is to say by her joining the Revival 60 Church (I have discussed her narrative of conversion elsewhere, 2007). They are associated with aural promptings from the angels who tell her to take action at particular moments.

Time and timing appear in several modes in Jeanette's account. (1) The aural appearance of the angels gives timely shape to her daily experience. (2) Jeanette's gifts allow her (inter alia) to 'see into' the flow of present happenings and to warn about the future. (3) Like the angels themselves, these gifts are atemporal or immutable; they preexist, and act with regard to, everyday experiences that are both mutable and (hence) difficult to decrypt. We can note how, when they are 'in the spirit', i.e. engaged in spiritually induced trance, Revivalists report a sensation of 'timelessness' (Wedenoja 1990:286).

As Jeanette's account shows, though, while it allows an escape from the temporal field of experience and provides a vantage point on it, the ecstatic form that access to this transcendent realm takes is emotionally discuptive. The envisioned conflict between the transcendent spiritual and the everyday temporal leads to a particular view of free will. Autonomy comes into play when Jeanette has to decide whether to act according to what the angels say or to defy them (according to the gifts she has). It falls to Jeanette to make a decision whether to undertake the task in question, sometimes at considerable cost to herself. Very often, either way, she finds herself compelled to undertake certain actions.

What Jeanette has to say about personal religious gifts fits closely with how wilson has described the various bases for acquiring a socially valued reputation in West Indian life (1973). As a personal quality, reputation can derive from evidence of virility, musical skill or more esoteric individual abilities such as preparing bush medicines or using obeah (witchcraft). Reputation is individualistic, egalitarian and unstandardised; personal ability in any domain can lead to positive repute (Wilson 1973:149-168). And, like the reputation value-frame more broadly, Revival gifts are unique and not commensurable by any objective-hierarchical standard in contrast to how, for example, book learning is valued. Describing the doorkeeper of her church, Jeanette underlines this essentially individualistic character of Revival gifts. 


\begin{abstract}
Some people get one humble gift, some get two, some get three, some get all five. You have this lady in my church; one gift she get. And that one gift - you ever hear of 'doorkeeper'? - she just come-a church and take one flag and stand up at the doorway there-so until church over; [then] she hang up her flag and go home. That is the only gift she get; stand up right at the church door. Every Sunday you come to church - the spirit tell you what $f i$ do you know, so you obey that - every sunday she come to church, take one flag, one blue flag, and she just stand up and hold it so [gestures]; right there until church over and you go out.
\end{abstract}

The fact, then, that gifts are 'humble' does not change their quality as unique forms of empowerment and repute. In her own case, it is the compulsive character of some of the gifts Jeanette has received that is most emphasised, as when she talks of her ability to 'run the road'; take long journeys on foot, without conscious awareness of her actions, in order to warn people of looming danger:

Some people get gift fi run the road - just gone, run the road you just gone run 'pon the road, you walk all from here [semirural Kingston] to downtown [central Kingston] and you don't know when you reach town and you no take bus! That's how - you see me - me get it myself - me get it myself... .

Me leave here...[to buy food] and when me realize, me did there at town and me there barefoot [we both chuckle]. And, same place where me go me are warn and go on; that same place everything happen, accident happen, accident man, chop up man.

It transpires that it is because Jeanette had already refused the request of the spirit to go (even though he asked her 'three times') that she finds herself in downtown Kingston in spite of her own wishes:

The spirit tell me fi go before, and quietly, and me wouldn't go... [M] decide say me not going downtown because me are no mad woman. Me always talk back [to the spirit]: 'me are no mad! Who are go downtown?! Not me. Me not going downtown!' And he say 'alright' [uses a soft voice mimicking the spirit]: he just say 'alright' - quietly - 'alright'. And me left here fi go look food fi go cook. All now, me no know where the food go because 
me reach downtown, barefoot, take off me shoes here an reach downtown... Me don't know nothing you know - most time you there like a [en]chant[ed] way.

Because of the mistreatment she receives from bystanders when she gives out warnings, the spirit urges Jeanette to visit a church in st Ann's parish. There a pastor envisions her wearing a 'gown', which she then sews in the red cloth worn by Revivalists. The gown, 'like...[a] priest's gown', makes her spiritual status apparent to others :

Me go way-a St Ann's and go a one church and visit; and the man... say; 'you! I see a gown wear 'pon you and I don't know how you going to hold into [come by] that gown'... Me go and make a gown, a big red gown, and the big red gown would be like, you know, priest's gown. You see how priest's gown stay? But it [is] red. That me must have ever clean and hang up; because me can wake up all four o'clock one morning have fi jump up and put it on; and when you come to, you are downtown. It happened to me three times already, yes...

The truth is that it is often difficult to separate the urgent voices of the spirits in Jeanette's narrative from the immanent gifts themselves. Sometimes it seems that it is the spirit that compels Jeanette to act, sometimes it is the interior gift. But a distinction emerges in terms of the kinds of interactions involved. Angels appear in many cases 'just like human beings' in their behaviour:

Like me come into the house and me see you, you just say 'good morning'; you have angel that come in and just say 'good morning' - so plain that when you just start to hear it you just start to all look out if you are mad or what. If are twelve o'clock him come say 'good afternoon', if are evening him come and say 'good evening'.

And likewise - and here complexities begin to multiply - interactions with spirits require the same kind of caution as pertains to relations with human beings.

Just like on earth you have good people, bad people; so you have bad angel and good angel. A bad angel will tell people to do bad things; good angels tell you to do good things... you [also] have 
two-fold angel... When me say two-fold angel, [it is] one angel but him two-fold: him can tell you bad and him can tell you good... It's you must control your mind and you know the bad angel from the good angel when they come. The bad angel come and say 'Huey, take up that plate there!' [she speaks sharply indicating a plate next to me that is projecting over the edge of the table]. And you should not take up the plate. The good one come [she speaks softly] 'Huey, you know say if that plate there stay there-so it may break?' - [scraping sound as I push the plate fully onto the table] Huey push back the plate! [laughter]

Types of interactions with spirits correspond with people's inherent gifts: for example, as Jeanette indicates, 'some people have gift from the Devil to do bad wicked things'. But (remember Wilson's proposition that a capability for obeah can form the basis of a reputation), even the gift 'to do bad' is uniquely personal and a potential thing of repute. Hence gifts separate themselves from the character of the spirit who gives them in as much as they can be recognised through introspection: they are part of one's self and are recognised as such by others. Contrastingly, angels and other spirits act in the social field like human beings; albeit that they are nontemporal and not human. Each Revivalist has his or her own personal angelic interlocutors - Jeanette mentions four - there is no shared pantheon.

So, just as each person has unique spiritual gifts within a heterogeneous field of human interaction, angels are likewise unique: they also have their specific incommensurable quiddities and powers deriving from an extra-temporal field that is never known in full. In the process of establishing the difference between her subjective intentions and her gifts (and the powers of the angels), Jeanette's self appears twice in her narrative, or in different aspects at least. First there is the set of a-temporal gifts and capacities that allow her to communicate with the angels and to act vis-à-vis temporal events. Then, in contrast, there is the self who is thrown in the midst of and, forced to endure, these events.

We can note important differences of emphasis between Revival and Pentecostalism (Austin 1997). In the Pentacostal nexus Christ exemplifies the perfection that individuals should strive to embody. Pentecostals can aspire toward personal progress and prosperity by dint of Christ-like self-sacrifice (e.g. Blanes 2013). Despite 
references to 'becoming a Christian', in Revival, Christ is only one figure amongst the spiritual multiplicity. Revival pictures a self amongst equals whose unique gifts (good, bad and ambivalent) can suddenly evidence themselves and be put to use for better or worse ends. Increasing knowledge of spiritual entities and their capacities is valued in Revival, personal progress and perfectability much less so. These divergent emphases suggest also distinct understandings of the politics of moral action in time: Pentecostals, even though they may draw on Revivalist healing or other techniques when needed, tend to describe Revival as obeah by another name (Wardle 2007:572-576).

\section{Urban cryptology and the End of All Things}

It is worth recombining aspects presented so far. Economically, Kingston is a resource poor but time abundant social arena for those we have been discussing. There is little urge to standardise a hierarchy of talents: small store is set on calibrating individual behaviour. Yet individuals need to, and do cooperate, in multiple ways. Human individuality is a foundational source of values even to the extent that harmful talents may be esteemed as bases for repute. So, while some view Jeanette as a 'madwoman' (even she does on occasion), others acknowledge her religious reputation (madness itself can have connotations of a spiritual gift). And, since objective standards of measurement are relatively weak when it comes to comprehending others, it is unsurprising that a considerable amount of time is spent decrypting people's intentions and in giving autobiographical form to personal experience through public narration.

In her 1952 study of Jamaican 'personality and conflict', Madeline Kerr notes the absence of group-oriented consensus in Jamaican social life: In any meeting, she remarks, 'there are usually as many opinions... as there are people present... It is as if the individual brings his own rules to the group and refuses to play by any other' (1952:171). Within limits, this description still holds well for those parts of the urban milieu where Revivalism thrives. And Kerr's observation raises a question about what we could term the cryptology of intentions: since each brings his or her own rules, how can any one person know another's aims? Because gifts can be used either for good or bad ends, another individual's powers are always dangerously ambiguous: but, as Jeanette's account shows, the self's own powers are ambiguous to itself too. 
Disagreeement and individuality of interpretation are difficult properties to discuss within the canons of ethnography. However, they gain conceptual depth and emotional significance from another quality of city life already mentioned - apocalyptic reasoning. In this respect, certain motifs in Jamaican religious life show remarkable recursion historically. As far back as the post-emancipation period (1838 onwards), there occur sporadic reports of 'women representing themselves as the Virgin Mary' and religious leaders called 'angels' pursuing and seizing practitioners of obeah. The Revivalist movement took shape in the $1860 \mathrm{~s}$ as a pre-millenial practice of public healing in balm yards and 'prophesying the destruction of life and property' (Sheller 1998:101-102). As Joseph Williams describes, the 1907 earthquake in Kingston gave particular intensity to these ideas: '[e]ven the Revivalist Bedwardites... sang... “it is a warning! It is a warning! On the dreadful judgement day, Heaven and earth will pass away. It is a warning!"' (1934:2-3). Williams collates reports of 'a man wearing a red mantle... [who] made his appearance in Kingston warning the people that before evening Kingston would be destroyed': a 'weird prophet... sounding a cry of warning' (1934:2).

Characteristically these prophet leaders were denounced by the colonial authorities as impostors or insane (Elkins 1977, Hill 2008). From the 1920s onwards, Rastafarianism took over from Revivalism the public task of apocalyptic revelation - reframing it in terms of an Afro-centric pan-nationalism. However, the general aspects recur into the present. In 1993, in the aftermath of a small (5.4 richter) tremor, I witnessed the archetypal narrative repeat itself. Just before the earthquake - as later told in a widely circulated story a Rastafarian stood up in court to prophesy an imminent hour of judgement; and, as the quake hit, everyone ran from the courtroom and the case was adjourned. For Rastafarians (drawing on the Book of Revelations) earthquakes are one sign of the End. Inside the University library, where I was during the event itself, I saw some people scramble quickly under desks, but also a dreadlocks at his desk droning a cry of judgement 'Jah, Rastafari! Jah Rastafari!'

This recurrent indexing of an End of All things centred in individual prophetic powers has one particular value from a viewpoint where the longer-term appears chaotic and unpredictable. When they call down Judgement, city dwellers collapse time and space in such a way as to bring the scale of social life into accord with the scale of individual experience and interpretation (Wardle 2000:198). 
Apocalypse offers a common horizon for diverse individual temporal orientations and standpoints. As such, even though it need not divert people from carrying out their everyday plans, the urban environment is dense with 'signs and wonders' that demand interpretation. The Bible, particularly its prophetic books, provides an abundance of images and phrases with which to interrogate the deceptive world of appearances. There is an urgent and omnipresent sense for many urban Jamaicans like Jeanette of 'being addressed'. ${ }^{1}$

These ideas gain widespread expression in the numbers games that urban Jamaicans play: sudden envisionings - rakes - become the basis for making a bet on particular numbers. Scanning the environment, suddenly an element foregrounds itself - a bottle of rum, a dropped bus ticket - this forms the basis for an interpretation and a play (Wardle 2005). The Jamaican Star Newspaper (online) currently runs a feature entitled 'Ketch de Rake... designed to help you understand your life experiences that often hold the secret to the numbers you need to play'. The aim of Rastafarian reasonings is, through a rhetorically elaborated dialogue, to uncover meanings hidden under the surface of social phenomena. For Rastafari, dreams evidence the true (concealed) meaning of contemporary political events (Homiak 1987). In both cases the signs are close to hand but only contingently activated.

It takes someone gifted with spiritual sight (a fouryeyed person), though, to see clearly through the darkened glass of the temporal to the timeless spiritual entities. Again, early Twentieth Century accounts describe 'Zions' who construe outsiders as 'in Babylon, unable to see heaven' (Elkins 1977:30). Chevannes quotes an elderly Bedwardite Revival Sister insisting that God is 'here with us' as opposed to 'up' in heaven:

For, up in the air, if somebody did live there, with a heap of - beg you pardon - shit would come down on us! Him is here with us... You is a power. You is a high man. You is a ruler... Every woman represent Jesus Christ mother standing before you (Chevannes 1994:86)

\footnotetext{
1 'Signs happen to us without respite, living means being addressed, we need only to present ourselves and to perceive. But the risk is too dangerous for us, the soundless thunderings seem to threaten us with annihilation...' (Buber 1955:10)
} 
In its typical form the temporal field is to a high degree undemarcated and hard to decrypt, but it becomes at moments difficult to ward off signs of the spiritual in the temporal as Jeanette's narrative attests.

In drawing this aspect of the discussion to a close it is striking how many long-historical features of religious expression Jeanette's narrative combines. Like many before her, Jeanette is called by angels to act morally within the urban sphere: her own actions are at certain moments synonymous with those of the angels who overtake her everyday body. She dons, like many before her in Kingston, a priest's gown in order to warn about an apocalyptic future whose signs and wonders are now becoming visible. Using immanent spiritual resources and with the assisting voices of the angels she is able to decrypt certain aspects of the present. And yet Jeanette is not simply reiterating well-known cultural tropes and symbols: she wears her gown in order for others to recognise her, but her religious experiences pre-date her attempt to find a cultural form for them (Wardle 2008); the spiritual entities involved remain inherently wilful and individual in character even while they help jeanette to give autobiographical meaning to her own experience.

\section{Concluding remarks}

Here I have explored the connection between a kind of reification of time, causality and the organization of a meaningful self in the urban Jamaican setting. The reification involved is not unique to cities or to urban Jamaicans, but it has particular ramifications in Kingston the Jamaican capital. Nietszche indicates how, when we say 'lightning flashes', we posit lightning twice, 'once as activity, once as subject': "we say "something flashing"... then look for an author of it... the lightning' (2006:76). When Revival zionists talk of atemporal spiritual gifts and of spiritual voices that cause church members to undertake certain kinds of acts, it seems that something analogous is in play. The enigmatic spiritual gift provides an index of permanence with specific effects on transient and often indecipherable social experiences. The Revivalist metaphysics parallels Kant's description of a homo noumenon - a foundational self that remains unchanged despite changes that occur over time in and to one's character (Kant 1983:99). The argument, then, has been that personal gifts and angelic presences anchor an otherwise freefloating sense of temporal experience. 
The problem of finding this stable point of reference, the search for a homo noumenon versus experience as a homo temporalis (cf. Arendt 1978:108), becomes particularly acute in a setting like Kingston. Not only is this an urban context but it continues to be built out of the individualising tactics and historic institutions of slavery and international labour migration. Revivalists respond to the problem in one way, but their worldview is by no means shared by all. Rastafarians, for example, have moved away from the polytheism in Revival toward a further divinisation and singularisation of self. Rasta speech replaces the creole 'me' with an 'I' that, in the case of the heartical Rastaman, is a divinely incorporative first person. 'We' for Rastas becomes 'I-n-I'; not a multiplicity of selves but a unity within myself (Wardle 2011). Rasta reasoning takes over some of the facets of the dynamic, ambiguous interior dialogue of the Revivalist. And, at least in its first years, Rastafarians resolved the eschatological problem of the End of All Things with the belief that, like their god-king Selassie-I, they were not destined to die unlike those around them; they would instead return to their home, Africa. Rastas nonetheless also call down angels on occasion.

Finally, it is worth noting Wedenoja's assertion that Revivalists are some of the best 'adjusted' members of their communities (1990:286). Even though we may question the meaning of adjustment in these circumstances, it seems that Revivalists strike one kind of balance between metaphysical and lived time. The absence of commanding institutional voices and reliance on elastic social networks-both of which are correlates of individualisation-add force to the search within for a noumenal self. This, in turn, gives temporal experience its spiritual accountability.

\section{References}

Austin-Broos. 1997. Jamaica Genesis. Chicago: Chicago University Press.

Bickerton, D. 1984. 'The Language Bioprogram Hypothesis' Behavioural and Brain Sciences $7(2): 173-221$.

Birth, K. 1999. Any Time is Trinidad Time: Social Meanings and Temporal Consciousness. Tampa: University of Florida Press. Blanes, R. 'Time for Self-Sacrifice: Politics and Ideals in African Prophetism' Ethnos 3(3:245-281 
Buber, M. 1955. Between Man and Man. Boston: Beacon Press.

Chevannes, B. 1994. Rastafari, Roots and Ideology. Syracuse: Syracuse University Press.

Coleman, S. 2011. "Right Now!": Historiopraxy and the Embodiment of Charismatic Temporalities' Ethnos 76(4):426-447.

Elkins 1977. Street preachers, faith healers and herb doctors in Jamaica. New York: Revisionist Press.

Eyre, L. 1986. 'The Effects of Political Terrorism on the Residential Location of the Poor in the Kingston Urban Region, Jamaica, West Indies'. Urban Geography. $7: 3: 227-242$.

Gell 1996. The Anthropology of Time: Cultural Constructions of Temporal Maps and Images. Oxford: Berg.

Guyer, J. 2007. Prophecy and the Near Future: Thoughts on Macroeconomic, Evangelical, and Punctuated Time. American Ethnologist, $34(3): 409-21$.

Hill, R. 2008. 'King Menelik's Nephew: Prince Thomas Mackarooroo, aka Prince Ludwig Menelik of Abyssinia'. Small Axe. 28(June): 15-44.

Homiak, J. 1987. 'The Mystic Revelation of Rasta Far-Eye: Visionary Communication in a Prophetic Movement' In Tedlock, B. (ed.) Dreaming: Anthropological and Psychological Interpretations. Cambridge:

Cambridge University Press, 220-224.

Horst, H. and D. Miller. 2006. The Cell Phone: An Anthropology of Communication. Oxford: Berg.

Kant, I. 1949. Critique of Pure Reason. New York: Macmillan.

Kant, I. 1983. 'The End of All Things' In Humphrey, T. (ed.)

Perpetual Peace and other Essays. Indianapolis: Hackett Publishing Co.

Kerr, M. 1952. Personality and conflict in Jamaica. London: Collins. Kral, L. 2006. Property Rights as a Precondition to Development: A Case Study of Jamaica. MA thesis. Duquesne University.

Maurer, B. 2001. 'Islands in the Net: Rewiring Technological and Financial Circuits in the "offshore" Caribbean'. Society for Comparative Study of Society and History 43(3):467-501

Mintz, S. 1961. 'Standards of Value and Units of Measure in the Fonddes-Negres Market Place' Journal of the Royal Anthropological

Institute 91:23-35.

Nietszche, F. 2006. Writings from the Late Notebooks. Cambridge: Cambridge University Press.

Patrick, P. 1999. Urban Jamaican Creole: Variations in the Mesolect. Amsterdam: John Benjamins.

Riesman, K. 1971. "Cultural And Linguistic Ambiguity: Some Observations on The Role of English-Based Creole In An Antiguan 
Village" In D. Hymes (ed.) Pidginization and Creolization of Languages. Cambridge: Cambridge University Press.

Robbins, Joel. 2001. 'Secrecy and the Sense of an Ending: Narrative, Time and Everyday Millenarianism in Papua New Guinea and in Christian Fundamentalism' Comparative Studies in Society and History, 4(3):52551 .

Seaga, E. 1969. 'Revival Cults in Jamaica' Jamaica Journal 3(2):3-15. Sheller, M. 1998. 'Quasheba, Mother, Queen: Black Women's Public Leadership and Political Protest in Post-Emancipation Jamaica, 183465. Slavery and Abolition, 19(3):90-117.

Wardle, H. 2000. An Ethnography of Cosmopolitanism in Kingston, Jamaica. New York: Edwin Mellen.

Wardle, H. 2005. A city of meanings: place and displacement in urban Jamaican self-framings. In Caribbean Narratives of Belonging (eds) $\mathrm{J}$. Besson \& K.F. Olwig, 79-93. Oxford: Macmillan.

Wardle, H. 2007.'A Groundwork for West Indian Cultural Openness' Journal of the Royal Anthropological Institute 13(3):567-583.

Wardle, H. 2010. 'The Double Life of M.G. Smith: Rethinking Caribbean Citizenship Beyond, Between and Within the National Frame' In Meeks, B. (ed.) M.G. Smith and the Emergence of Social Anthropology and Social Theory in the Caribbean and Beyond. Mona: University of the West Indies Press.

Wardle, H. 2011. 'I, Me, Myself y Los Dilemas de la Voluntad en Kingston, Jamaica'. Maguare. $25(2): 11-39$.

Wedenoja, W. 1989. 'Mothering and the Practice of "Balm" in Jamaica' in Shepherd McClain (ed.) Women as Healers: Cross Cultural

Perspectives. New Brunswick: Rutgers University Press.

Wedenoja, W. 1990. 'Ritual Trance and Catharsis: A Psychobiological and Evolutionary Perspective' in Jordan, D. and M. Schwartz (eds) Personality and the Cultural Construction of Society. London: The University of Alabama Press.

Williams, J. 1934. Psychic Phenomena of Jamaica. New York: Dial Press. 